\title{
Habitus, Field and Capital in Translation and Publication of Picture Books - a Case Study on Peng Yi
}

\author{
Wei Song \\ College of Foreign Languages and Cultures \\ Sichuan University \\ Chengdu, China
}

\begin{abstract}
In light of Bourdieu's Social Practice Theory, this paper aims to explore the intertwined factors of habitus, field and capital in translation and publication of picture books. The analysis of translation and publication related issues will be conducted with the case study on Peng Yi, who is the most renowned and productive translator of children's picture books in mainland China.
\end{abstract}

Keywords-Peng Yi; picture books; translation; habitus; field; capital

\section{INTRODUCTION}

Peng $\mathrm{Yi}$ is the most productive picture book translator of China, whose identity was commonly known as a children's literature writer back to the mid 1980s. In his multiple identity-transference from a film director to a writer, photographer, translator and professor, he has been consistently gaining capital both in academia of children's literature and outside it in the book market of children's readings.

One of Peng's hobbies in childhood was sketching the insects, and he used to dream of becoming an entomologist who would be able to bury himself in the world of insect specimens. With dreams coming and going, Peng Yi never stays far from what he was obsessed with in childhood. Fantasy is not only the central focus of Peng's writing and translation, but also the bottom color of his life.

\section{AN OVERVIEW OF PICTURE BOOKS}

\section{A. Definition to Picture Books}

As a quite boundaryless concept, picture books are hard to define. Researchers who have been seeking for a definition once for all may only end in vain. "It's a tough task to define picture books, for it's quite an inclusive concept of huge varieties, whose boundaries seem to be rather blurred [1]." In light of different angles through which we see a picture book, it could either be "an item of manufacturer and a commercial product; a social, cultural, historical document" or "an experience for the child" [2]. It's commonly recognized that picture books are mostly aiming at children readers. "A picture book combines visual and verbal narratives in a book format, most often aimed at young children." [3]

With the obvious features of dually narrative mode, picture books combine pictures and words as an integrated narration subject. And in the wordless books, pictures alone function as the independent subject of narration. Nodelman defines picture books as books that "intended for young children which communicate information or tell stories through a series of many pictures combined with relatively slight texts or no texts at all". [4] Picture books enjoy a long tradition of shared-reading between parents and the children in the west, thus picture books "meant to be read aloud by an adult, who dramatizes the story in the course of reading". [5] Picture books also appeal to adult readers for their innocent and imaginative ways of expressing subtle emotions, and they can "touch our emotions, delight our senses, appeal to our whimsy, and bring back memories of our childhood." [6]

In reviewing how leading researchers in the field of children's literature studies define picture books, Oittinen classifies picture books through the different roles they are functioning, namely, the picture book as a type of book, the picture book as words and images, the picture book as sequence, the picture book as performance for an audience, the picture book as a pedagogical tool for children and the picture book as an art. [7]

\section{B. History of Picture Books}

The history of picture books could be traced back to the mid of the 17th century. John Anos Comenius, a reputable Czechic educator of the time, got his Orbis Sensualium Picutus published in Nuremburg, which is regarded as the earliest publication of picture books in the world [1]. In China, traditional picture books are called xiaorenshu (literally meaning story books for children), whose story clues are adapted from China's classical fictions. Different from western picture books initially written and drawn to educate and inspire children, Chinese xiaorenshu didn't have a definite goal to serve the children readers. Thus, similar to the birth of China's modern children's literature in general, the booming phenomenon of picture books in China at the threshold of the century owed greatly to western picture book heritage. 


\section{Awards of Picture Books}

Among the three leading picture book awards of the world, Hans Christian Anderson Award was named after Anderson, the Dannish children's literature master, the other two, Caldecott Medal and Kate Grennway Medal were set in honor of the greatest figures in western picture book history, Randolph Caldecott and Kate Greenway. Interestingly, Caldecott and Greenway was born in the same year (1846), which was not a mere coincidence, but an amazing mirror to reflect the long-standing tradition of western picture books.

"The work of art, like religious goods or services, amulets or various sacraments, receives values only from collective belief as collective misrecognition, collectively produced and reproduced." [8]

In cultural reproduction, awards conferred are regarded as symbols of capital closely attached to books and other cultural products. Peng's name as the translator and recommender of picture book reading programs has been frequently linked to the award-winning works and writers of the world. Hans Anderson Award, Caldecott Medal, Kate Greenway Medal, Newbery Medal, Library of Congress, Best Books for Children, 100 Best Books for Children NEA, Parents' Choice Award Winners: Picture Books, Golden Kite Best Picture Illustration Award, Mother Goose Award, "Golden Apple" Biennale of Illustrations, Bratislava, Czechoslovakia, Picture Book Award of Japan, Japan School Library Association Best Picture Book Award, IBBY Honor List Winner are just few of the long list of the most renowned picture book awards of the world. The United States, Europe, Japan and Korea are four most important powerhouses of picture book production. With English becoming the global lingua franca, most picture book awards have been set and granted on the basis of English language.

\section{A SOCIOLOGICAl CASE STUDY}

\section{A. Peng Yi's Habitus}

"The habitus is a set of dispositions which incline agents to act and react in certain ways. The dispositions generate practices, perceptions and attitudes which are 'regular' without being consciously co-coordinated or governed by any 'rule'...dispositions are acquired through a gradual process of inculcation in which early childhood experiences are particularly important." [9]

Peng Yi was born in an intellectual family of Shenyang in 1958, whose father was a professor of Northeast University (formerly known as Northeast University of Technology) and his mother a doctor of a local hospital. Different from the ordinary working-class families in which parents' vision might be very much restricted by financial incapability or limited education, "Peng's family had a very easy atmosphere. His parents were quite optimistic and humorous, and seldom lost their temper randomly. This helped shape Peng Yi's personality, lively, outgoing and innocent." [10] The world of children is full of imagination, curiosity and adventure. Their love for animals and nature arouses endless questions and crazy ideas. Children lucky enough to be born in well-off families with loving parents enjoy more freedom in childhood and thus have more possibilities to bring out their inner best. The most precious thing freedom presents children with is the critical way of thinking.

The habitus of Peng Yi is deeply rooted in the way how his parents raised and instructed him in his early childhood, and his decision-making strategies for study and career never seemed to be stereotyped but a resonance of his heartbeat. He obtained his BA of entomology, MA of pedagogy and Ph. $\mathrm{D}$ of literature from Fudan University (Shanghai), Tokyo Gakugei University and Shanghai Normal University successively. The cross-disciplinary educational background endowed him with insightful sensitivity to nature, education and literary aestheticism. Peng's name was widely known as one of the two leading Shanghai writers of the Fantasy school (re'nao pai) of children's literature in the early 1980's, the other being Zhou Rui, who has been still regarded as one of the best writers of children's literature in China up till today. Peng's preference for fantasy writing echoes subtlety the literary style of Naoko Awa (あわなおこ), who is one of the most reputable writers of children's literature in Contemporary Japan. However, it's not a mere coincidence that Peng took entomology as his major in the first place but chose to study overseas for pedagogy in Japan some years later.

The major of entomology is concerned with insects and all the other related issues in nature. For majority of graduates majoring in entomology in the early 1980's of China (Peng graduated from Fudan University in 1982), they were most likely to become techniques or professionals in biology-related fields. Peng's first job after graduation was concerned with insect control at the East China Grain Bureau (Shanghai) but he stayed at the position for just one day and quit. Soon after that, Peng took a job offer from Shanghai Science and Education Film Studio and worked as a director temporarily, where he began to be obsessed with writing children's literature.

The academic training Peng received in entomology didn't make him an entomologist but an expert in translating the picture book of The Records about Insects series published in Japan, which owes inspiration to the academic and literary canon Souvenirs Entomologiques by French entomologist Jean-Henri Casimir Fabre. His translation of Fabre was not only an echo to his academic reading during undergraduate days, but also a salute to children's mostbeloved genres of literature.

Peng's translation of Japanese picture books has covered almost all the major picture book writers of Japan. On the long list of Japanese writers whose picture books Peng introduced to Chinese readers, many had owned literary reputation in Japan and had won the leading awards for Japanese children's literature before his translation. The bestknown Japanese picture books by Harou Fukami (ふかみはる お), Noritake Suzuki (すずきのりたけ), Hide Koise (いせひで こ), Tatuya Miyanishi (みやにしたつや), Yoshiharu Tutida (つ ちだよしはる), Yushihumi Hasegawa（はせがわよしふみ), Kazuo Iwamura (しわむらかずお), Tatuhide Matuoka (まつお かたつひで), Kenzi Miyazawa(みやざわ けんじ), Rintaro 
Utida(うちだりんたろう), Nankiti Niimi(にいみなんきち), Kyo Yamawaki (やまわききょう), Kesaburo Tejima (てじまけ いさふろう), Tadashi Akiyama (あきやまただし), Shiro Yadama (やだましろう) all have their translated versions in Chinese owing to the translation by Peng, some of which were co-translated by Zhou Longmei ${ }^{1}$.

In addition to his translation of Japanese picture books, Peng has also translated a great number of picture books of English, most of which are co-translated with his wife Yang Lingling $^{2}$ who used to be a visiting scholar on fantasy children's literature of the west at Internationale Jugendbibliothek ${ }^{3}$ (The International Youth Library). Similar to the Gestalt effect, the combination of fame of Peng Yi and Yang Lingling as translators exceeds that of their fame individually. Constant partnership of them as co-translators has formed a steady impression of quality translation, for they also have a good many translated works in their respective names. In the meantime, frequent exposure of Peng Yi and Yang Lingling as co-translators to the picture books of English has also formed a fixed impression in readers' reception. Like wise, the partnership of Peng Yi and Zhou Longmei renders the same influence on reader's reception.

When asked what made a good writer of children's literature, Peng said "Joys obtained through reading a good story will be always engraved on a child reader's mind...child readers should never be fooled or put off, which must be the motto of those who write for children." [10] This has been always what Peng Yi holds fast to in choosing what to write and what to translate.

Night on the Galactic Railroad is a posthumous fantasy by Kenzi Miyazawa, one of the most read writers of children's literature in contemporary Japan. "Different from other readable fictions by Kenzi Miyazawa, this fantasy is full of images that mirror the author's value towards life and death, philosophy and religion and is hard to understand for child readers...for child readers, it matters not whether they truly understand a story or not; what matters is whether they have read it." [12] As one of the earliest translators of Kenzi Miyazawa, the way how Peng comments on this fantasy fiction properly showcases his aesthetic preference in writing and translating. Picture books arouse empathy of people regardless of culture and age. And what contributes to Peng's life and career choices as a picture and fantasy lover is the hidden habitus that shapes his personality.

Zhou Longmei is a Chinese female translator of Japanese who has taken a teaching position at Saga University of Japan. Zhou is most renowned translator of Naoko Awa, Kenzi Miyazawa and Nankiti Niimi. Yang Lingling graduated from Shanghai University of Traditional Chinese Medicine, whose name is mostly known in cotranslation of children's picture books with her husband Peng Yi.

The International Youth Library (IYL) (Internationale Jugend bibliothek, IJB) in Munich is a library that specializes in the collection of children and youth literature from around the world in order to make them available to the public, focusing on the international community. This library is the largest of its kind worldwide, and has been operating since June 1983, in Blutenburg Castle in the Munich district Obermenzing, before this time the library was located in Schwabing.

\section{B. The Field of Picture Book Translation}

The internet-based book promoting and retailing mode puts Peng's name and fame together with the dazzling awards of all the sorts. For most of the parent readers, they generally have a vague concept about the real significance of the awards a picture book has ever received in the source language, yet they may as well be impressed by repetitively seeing Peng's name on book covers, dust jackets and girdles. In the field of children's picture book translation and publishing, Peng's name is an appealing symbol that publishing institutions never stop pursuing, for what Peng's name brings is of the greatest value linked to their expectations for publishing profits. In this sense, Peng's identity as an expert in writing, translating and promoting children's literature sees a comprehensive integration and magnification against the backdrop of online mode of book consumption.

In order to explore further about the publication of translated picture books by Peng $\mathrm{Yi}$, the author has made an analysis of his translated picture books for sale during the past 20 years or so based on dangdang.com, the biggest online transaction platform of books in China. The statistics show that the earliest picture book Peng translated was Shiro Yadama's It's Raining Pigs on Sunny Days published by 21st Century Publishing House in 1999. "Fantasy" has been always the thing where Peng's interest of writing and translating lies. The genres of the literature Peng has translated during the past two decades are quite diversified, yet showing fixed inclination for fantasy styles. He has translated approximately 450 picture books, most of which are of a set of story series.

"The social space is so constructed that agents who occupy similar or close positions are placed in similar conditions and submitted to similar conditionings, and have every chance of having similar dispositions and interests, and thus of producing practices that are themselves similar." [12]

The top five publishing houses that Peng has been in cooperation with are Beijing United Publishing House (Beijing), Guizhou People's Publishing House (Guiyang), Jieli Publishing House (Nanning), 21st Century Publishing House (Nanchang) and Changjiang Children's Publishing House (Wuhan), through the ranking of which the capital operation mechanism in publication of picture books could be vividly seen. Beijing is one of the origins where modern children's literature of China started (the other being Shanghai). As the political centre of China, Beijing gathers the largest amount of cultural resources of China. In addition to Beijing United Publishing House, other publishing institutions in Beijing as well compete for publication of translated picture books by Peng Yi, among which include China Comic Press, New Star Press, People's Literature Press, Qsinghua University Press and 10 other publishing houses.

Of the 450 picture books (picture book series), Peng has translated since 1999 , over 150 of them got published in Beijing, taking up $1 / 3$ of the total. The rest of top 4 publishing houses through which Peng's translated picture books were published are either traditional presses for 
children's readings or institutions bearing quite successful experience in publishing best-selling picture books. Take Guizhou People's Publishing House for instance, its success in publishing Magic School Bus series was such a hit that the press has been constantly expanding its business in the related areas.

"To exist socially means to occupy a determined position in the social structure and to bear the marks of it..., it also means to depend on, to hold to and to be held by, in short, to belong to groups and be enclosed in networks of relations ...which show themselves in the form of obligations, debts and duties — in short controls and constraints [8]." Peng's early years' drawing experience turned out to be important capital in his career. In translation of picture books, the empathy that Peng invariably harbors towards picture classics from other parts of the world is a resonation of his insights into color, shades, lines, angles as well as blank-leaving techniques in drawing. Therefore, the concepts of drawing such as the inspective perspective, depression angle, elevation angle and flat angle, so on and so forth that are highly of professional scope are analyzed in appreciation of picture books [1].

In addition to this, Peng's sensitivity to the overall designing mechanism and printing style of picture books is fully reflected on his attention paid to subtle elements involved in the details of dust jackets and end papers. Peng cites Anthony Browne's My Mom \& My Dad to demonstrate that the pictures of end papers after the front cover and before the back cover adopt the similar patterns to that of the mother and father's pajamas respectively [1].

Barbara Cooney, Caldecott Medal winner for twice, describes the relationship between pictures and words with a pearl-thread-necklace metaphor, "A picture book is a pearl necklace, pictures being the pearls and words the thread to string the pearls up into a necklace." [1] Peng's perspective of seeing picture books is highly artistic, regarding them as music and films. His musical perspective mobilizes the basic elements of tempo and rhythm of music, which combine to express the scene of a story in picture books. For instance, the repetitiveness of pictures and words of a page is described as tempo 2/4, 3/4 and 4/4. He cites John Birmingham's Mr. Grumpy's Outing and the Fifth One by Norman Junge as the example of tempo $2 / 4$ and 3/4 respectively in his Reading and Classics of the World Picture Books, which is one of the few important academic monograph on picture books in mainland China [1].

Peng Yi's perspective of seeing the picture book translation through music and drawing echoes that of Oittine's ideas, "Translators of picture books should be aware of the different potentials of expression, such as tone, intonation, tempo, and pauses, and contribute in everyway possible to the aloud-reader's enjoyment of the story, which, in turn, contributes to the child reader's enjoyment of the story." [6] In the meantime, Peng's working experience as a photographer and film director provides him with possibilities of seeing picture books in scope of time and space [1].

\section{Peng's Capital in Picture Book Translation}

The translators' profile in areas of children's literature and specifically in the realm of picture book translation is very special, for most translators have full-time profession outside translation. Editors, writers and professors are the most probable occupations of translators of children's writings. Owing to the booming market of picture book translation and publishing during the past fifteen years in China, domestic publishing houses of China not only compete against one another for the awarded best-sellers, but also the foreseeable profit margin. In accordance to the rule how cultural capital flows and functions from high to low, the leading translators of picture books are those who have obtained their reputation in areas of children's literature or translation of children's literature. Japan is one of the most influential countries in picture books while Japanese is not as commonly used as a lingua franca like English.

The scarcity of professional translators in Japanese literature contrasts with the abundance of picture books introduced to China. In the very beginning stage when Japanese picture books were translated into Chinese, Peng was one of the only few reputable figures in the field, and the cultural capital he had already obtained as a children's literature writer was further strengthened when more and more Japanese picture books were connected with his identity as a picture book translator.

Since Peng completed his $\mathrm{PhD}$, he has been working with Zhejiang Normal University (ZNU), which is renowned for its children's literature studies in China. Peng's capital accumulated in the field of children's literature increasingly rose by means of gaining an academic status outside his professional realm of writing and translating for children. However, Peng's capital as a translator of picture books doesn't merely derive from what he has translated, but from what he has written and edited for children and also from what he has explored in all relevant arenas linked to children's literature. Peng's working history as film director, editor, photographer, writer, translator and researcher sees many overlappings, through which his identity is uniquely formed.

Most of the picture books Peng has translated have a long list of awards, taking Leo Lionni's Swimmy [14] for example, it had been awarded with 7 major prizes for picture books since its publishing in 1963, including Silver Award of Caldecott Medal 1964, New York Times Best Illustrated Book 1963, ALA Notable Children's Books 1963, German Youth Book Award, Picture Book Category 1965, New York Times 50 Best Books of the Past 50 Years 1966, "Golden Apple" Biennale of Illustrations, Bratislava, Czechoslovakia 1967 and Japan Children's Book Association 500 Picture Books for Children [1].

Peng $\mathrm{Yi}$ as a reputable figure in reading promoting programs for children offers less well-known authors and translators a channel of being recognized by publishing institutions and hereafter promoted to the readers, because "the literary field...involves the capital - the capital of the established author which can be partly transferred into the account of a young and still unknown author by a highly 
positive review or preface." [13] His capital gained in writing and translating children's literature has not only brought new possibilities for him but also created opportunities to those who haven't yet been fully recognized in the field.

In the field of children's literature, Peng Yi has been obtaining his capital since his first published story Tuhuhu's Adventure in 1985 by Anhui Children's Publishing House, through which he is labeled as one of the two leading writers of the Fantasy school of Shanghai in the 1980s. His capital sees a further strengthening with his six years' overseas experience in Japan, where he obtained sufficient skills of writing and translating fantasy literature. Chinese domestic market for picture books saw a thriving growth during the past decade, and Peng's name as a writer, translator and recommender of parent-child readings was recognized as a label of authority in the field of picture books.

His capital accumulated not only functions well inside the academic circle of children's literature but is equally functioning outside it. The rising of middle-class families owing to China's constant opening-up and enlargement of enrollment of tertiary education renders an inherent demand for more quality-oriented education of children. As the major consuming group of picture books, middle-class parent readers are extremely sensitive to award-winning information and the title that a writer, translator and recommender bears. Thus, outside the academia, the exposure of Peng's name on picture book covers, dust jackets or girdles sees a conversion of Peng's capital into brand consumption of some kind.

\section{CONCLUSION}

The field of picture books is an obvious subfield subordinated and governed by the field of literature in general, thus Peng's reputation initially built in writing children's literature gained him a proper channel of entering the field. Peng's educational background of 3 different stages in undergraduate, postgraduate and doctoral studies have all contributed and made him the way he is as the most reputable picture book translator of China. The capital Peng has gained in the field of children's literature over the past years owes substantially to his multiple roles played in writing, translating, editing and recommending. However his roles transferred, Peng has always remained his habitus acquired since early childhood days, which shapes his world of writing and translating a utopia full of innocence, adventures and fantasies.

\section{REFERENCES}

[1] Peng Yi. Reading and Classics of the World Picture Books [M]. Nanning: Jieli Publishing House, 2018.

[2] Bader, Babara. American Picuture Books from Noah's Ark to the Beast within [M]. New York: Macmillan Publishing Co., 1976.

[3] https://en.wikipedia.org/wiki/Picture_book.

[4] Nodelman, Perry. Words about Pictures [M]. Athens: University of Georgia Press, 1988.
[5] Sezzi, Annalisa. 2010. Borders of Children's Literature: The Reception Picrture Books in Italy and the Question of Reading Aloud [J]. Przekladaniec: A Journal of Literary Translation, 22-23:197.

[6] Michell, Diana. Children's Literature: an Invitation to the World [M] Boston: Allyn \& Bacon, 2002.

[7] Oittinen, Ritta, Anne Ketola, Melissa Garavini. Translating Picturebooks: Revoicing the Verbal, the Visual and the Aural for a Child Audience [M]. New York and London: Routlege, 2018.

[8] Bouridieu, Pierre. The Rules of Art: Genesis and Structure of the Literary Field [M]. California: Stanford University Press, 1996.

[9] Bourdieu, Pierre. Language and Symbolic Power [M]. Cambridge: Polity Press, 1991.

[10] Zhuang Dawei. Innocence of a Big Man - Anecdotes of Peng Yi [J]. Journal of Family Education, 1996(03):22-23.

[11] Song Ping. Peng Yi: Keeping a gate for children's literature [N] China Reading Weekly, 2013-12-18(012).

[12] Peng Yi. Night on the Galactic Road: Forever Story Unfinished [N]. Journal of Literature and Art, 2016-02-26(006):2.

[13] Bourdieu, Pierre. In Other Words - Eassays towards a Reflexive Sociology [M]. California: Stanford University Press, 1990.

[14] Leo Lioni, tr. by Peng Yi. Swimmy[M]. Haikou: Nanhai Publishing Co. 2007. 